as well as the educational, value of such a system is urged.

School Gardens: Miss Louise KLein MILLER, director of the Lowthrope School of Horticulture and Landscape Gardening for Women.

Educators are becoming alive to the importance of school gardens as a potent factor in education, and the next five years will see rapid progress in this direction.

The schools of Europe are far in advance of us in this phase of education, and the agricultural and horticultural progress is largely due to the efficiency of the school gardens. In Austria-Hungary alone there are 18,000 school gardens. In France, the teachers are required by law to be able to instruct their pupils in the elements of agriculture and horticulture, and normal schools have been established for the pur. pose of giving teachers such training. No plans for school buildings to which the state contributes are approved unless accompanied by plans for a school garden. The study of horticulture is compulsory in Belgium. In Germany and England, school gardens are encouraged, but not regulated by law. Some excellent work has been done in this country, but in many instances the educative features have been made subservient to the raising of vegetables.

The theory and practice of gardening satisfies certain dominant interests in a child's physical, mental and moral evolution; affords an opportunity to expend normally and naturally often misdirected energy; develops an appreciation of the. proper values of things; quickens a knowledge of the close interrelations in nature; gives fundamental principles of great economic significance; suggests some of the great problems in the struggle for existence; teaches the dignity of labor and personal responsibility.
The day is not far distant when a supervisor of school gardens will be as important an officer in a school system as a supervisor of music or drawing. Children are not satisfied with evasive answers. They are alert, inquisitive and intelligent, and a teacher who wishes to gain their confidence and keep their respect must be able to respond to most of the demands made upon her, and have her knowledge at her tongue's end and finger tips. This is an open field for women, and in this capacity an earnest, capable and enthusiastic teacher can render valuable service to the public good.

A difficult problem for the economist and sociologist to solve is the herding together of a large population in a crowded city. Strenuous efforts are being made to turn the tide countryward, and induce persons to seek homes where life will be freer and more wholesome. If the elements of agriculture and horticulture were taught in country, town and, so far. as possible, in city schools, in an intelligent, scientific and attractive manner, life in the country would be the joy that the opportunity affords.

FranK H. HitchCOCK, Secretary.

\section{THE UPPER TEMPERATURE LIMITS OF LIFE.*}

THE upper temperature limits of continued and active life are possible of observation most satisfactorily in the case of the organisms inhabiting hot springs. Such springs are widely distributed in both hemispheres and vary in temperature from tepid to boiling. In all these springs, except in the very hottest waters and in those in which there is something in the chemical composition which prevents, organisms have been found. Various indi-

* Abstract of an address before the California Chapter of the Sigma Xi, Berkeley, April 28, 1903. 
vidual references have been made to the organisms living at higher temperatures in such springs, such as are tabulated by Davenport in his ' Experimental Morphology' (Vol. I., pp. 249-267), under the heading of 'Acclimatization to Heat.' As may be seen from the references there given, and more particularly from Davenport's notes on the different records, as well as from an examination of the records themselves, there is a very decided lack of good strong evidence as to exact temperatures and the kinds of organisms occurring at the temperatures given or hinted at. The records are largely of isolated observations, generally made incidentally and without, in any case, being a portion of any extensive work to determine temperature limits. As far as the literature goes, there seems to have been nothing systematic attempted along these lines.

It has been my own good fortune to study with considerable care and thoroughness the thermal organisms of several distinct regions. The first observations were made at the Arrowhead and Waterman Hot Springs near San Bernardino, California, being introduced to them through the kindness of Mr. S. B. Parish of that city. The visits made to these springs were three in number, in as many different years. The organisms of the hot waters of the so-called geysers in Sonoma County, California, as well as those of several minor hot springs near Calistoga, in Napa County of the same state, were collected and the temperatures carefully noted in June, 1900. In August, 1898, ten days were spent in the Yellowstone National Park, under the auspices of the United States Geological Survey, examining the life in the hot waters of the Mammoth Hot Springs, the Norris, Lower, Middle and Upper Geyser Basins, the Lakeshore Hot Springs, and of other lesser collections of springs. In all, several hundreds of gatherings have been made, the specimens carefully preserved and studied, and the results are awaiting publication. Among other things, especial care was taken to determine accurately and record the exact temperature at which each specimen was growing, so that the data of this character might be complete for the whole series. Not only were the highest temperatures at which living organisms were found, taken, but the temperatures of all organisms inhabiting strictly thermal waters. The results of all my own observations agree perfectly and present a series of facts somewhat at variance, at least in certain essential details, with the results of other observations as tabulated by Davenport. Many, or even the large majority, of the discrepancies disappear, or may be plausibly explained, however, when one considers how erroneous certain temperature observations may be, unless taken with certain precautions.

In my own work it was found very soon that, unless very considerable care was exercised, the temperatures were not those at which the organism was living. It was found, for instance, that it was extremely misleading to take the temperature of a spring and then credit the temperature of any organism existing at any distance from that point as being the same. The central portion of a spring with shallow margins may be of a considerably higher temperature than the margins. In the case of streams, the temperature of two points only a few centimeters distant from one another may differ $10^{\circ}-15^{\circ} \mathrm{C}$. on account of currents imperceptible except to the thermometer. Especially is this likely to be the case in springs or overflows into which colder currents come from side streams, whether these be of thermal or cold waters. The temperatures of masses 
of organisms partly or wholly emergent from the waters are difficult to ascertain with certainty, but in the majority of such cases which have come under my own observation, the only living portions of such masses were comparatively cool. The temperatures which seem sufficiently certain to place implicit confidence in were taken with the following precautions: (1) temperatures only of submerged tufts were taken; (2) the bulb of the thermometer was placed within, or just at, the sample which was removed and preserved for microscopical study; and (3) in a very considerable number of cases, particularly of the highest temperatures noted, samples and temperatures were taken at the same spot on different days, or times of the year.

The results of all these observations, taken with the precautions indicated above, give certain general results for the strictly thermal waters-i. e., for waters over $43^{\circ}-45^{\circ} \mathrm{C}$. The temperature results may be indicated under a number of different heads :

1. No animals were found in strictly thermal waters, although careful search was always made for them.

2. No living diatoms were found in strictly thermal waters. At times, a few empty valves were found, but these may easily have been blown in, since the localities were in the neighborhood of extensive areas of diatomaceous earth.

3. All the organisms found in my own collecting in strictly thermal waters belong to the groups of plants designated as Schizophyta, being either Schizophyceæ (Cyanophyceæ) or Schizomycetes (Bacteria). These two groups possess a simple morphology and peculiar cell-structure.

4. The chlorophyllose Schizophyceæ' (or Cyanophycex) commonly continue up to $65^{\circ}-68^{\circ} \mathrm{C}$., and in some cases, but scantily, up to $75^{\circ}-77^{\circ} \mathrm{C}$.

5. The chlorophylless Schizomycetes (or bacterial forms) endure the highest temperatures observed for living organisms, being abundant at $70^{\circ}-71^{\circ} \mathrm{C}$. and being found in some considerable quantity at $82^{\circ} \mathrm{C}$. and at $89^{\circ} \mathrm{C}$.

6. The temperature of $89^{\circ} \mathrm{C}$. is the highest at which I have been able to find any organisms living. This temperature was taken at several different times and on two separate days. The organism belongs to the filamentous Schizomycetes. Search was made most carefully at the 'geysers' of Sonoma County, California, for green organisms at $93^{\circ} \mathrm{C}$., as recorded by Brewer, but no life was observed at any temperature above $68^{\circ} \mathrm{C}$.

7. Living organisms were found at higher temperatures' in siliceous waters than in calcareous waters.

8. The limits of life in the siliceous waters, as determined by my own observations, are between $75^{\circ}$ C. and $77^{\circ}$ C. for chlorophyllose, and $89^{\circ}$ C. for chlorophylless Schizophyta.

9. The limits of life in the calcareous waters, as determined by my own observations, are between $60^{\circ} \mathrm{C}$. and $63^{\circ} \mathrm{C}$. for chlorophyllose Schizophyta and between $70^{\circ}$ C. and $71^{\circ}$ C. for chlorophylless Schizophyta.

10. No organisms were found in springs reputed to have a decided acid reaction. This needs more study, but where a strong acid (sulphuric) character is given for a spring, the waters are free even from Schizophyta.

A careful study of the species of thermal Schizophyta shows several details of interest. They are either filamentous or unicellular, but in each case the filaments or cells are enclosed within a jelly, usually abundant. Within the strictly thermal 
limits, only one member of the higher and heterocysted Cyanophyceæ has been noted, viz., Hapalosiphon laminosus. This species does not reach the upper temperature limits, even for the chlorophyllose forms. The majority of the chlorophyllose forms are either species of Phormidium or unicellular forms peculiar, as far as known at present, to the thermal waters. The chlorophylless forms, as far as detected, are filamentous, very slender, and belong to the group known as the sulphur bacteria. All of these forms are very closely related, even the so-called sulphur bacteria being little else than colorless species of Phormidium. A matter to be emphasized is this-that all of the strictly thermal organisms are low forms, not even representing the higher differentiation in the group to which they belong.

The question is always raised, in the case of the thermal organisms, as to the nature of the protoplasmic contents of the cells. What is it that enables the protoplasm of the thermal organisms to withstand a temperature which coagulates, and consequently kills, the protoplasm of the majority of organisms. We find that when a proteid, like egg albumen, is free from water, it does not coagulate at the very highest temperatures which leave it unburned, and that the less the content of water, the higher the temperature of coagulation. The cell structure in the Schizophyta is peculiar, being quite different from that of other groups of organisms. While the details are not satisfactorily settled, there seems to be a certainty that there is less differentiation than in other groups. Whether we believe that the protoplast is all nucleus or whether we believe that it is all cytoplasm, it remains clear that it is different from the protoplast of other groups of organisms and affords us room for surmise. There is nothing, so far as my own study of the Cyanophyceæ cell is concerned, to indicate that the protoplasm contains so little water as to render it incoagulable by the higher temperatures which it endures. It seems rather that there may be some important difference in the essential proteids of the mixture, or in the nature of the constitution of the substance, if it be regarded as simple, which renders it less coagulable, a difference similar to that existing between a substance of the group of the vitellins and one of the group of the globulins.

William Albert Setchelt.

\section{SCIENTIFIC BOOKS.}

THE SUGAR INDUSTRY.

Anleitung zur Untersuchung der für die Zuckerindustrie in Betracht kommenden Rohmaterialien, Produkte, Nebenprodukte und Hilfssubstanzen. Sechste umgearbeitete und vermehrte Auflage. Von $\mathrm{R}$. FrüHLING. Braunschweig, Friedrich Vieweg und Sohn. 1903. Pp. xxi +505 . Marks 12.00.

The rapid advances made in sugar chemistry within the past few years have necessitated a thorough revision of and the introduction of a considerable amount of new matter in this, the sixth, edition of Frühling's 'Anleitung.'

Examination of the book shows that the author has spared no pains to do justice to his self-imposed task.

Adoption of the regulations of the International Commission for Uniform Methods of Sugar Analysis, Paris, July 24, 1900, has of course resulted in the introduction of fundamental changes. The metric cubic centimeter has replaced the Mohr cubic centimeter; the normal sugar weight is now 26,000 grams instead of 26,048 grams; $20^{\circ}$ Centigrade has been accepted as the standard temperature for the preparation and the polarization of sugar solutions. Space is given to the extensive table showing the relation between the specific gravity of sucrose solutions at $20^{\circ} \mathrm{C}$. and the sucrose percentage of such 